\title{
Pengembangan Koperasi Daur Sampah Untuk Meningkatkan Kesejahteraan Masyarakat Kampung Code di Kota Yogyakarta
}

\author{
Panji Kusuma $P^{1}$, Jalu Aji Prakoso ${ }^{2}$ \\ 1,2, Fakultas Ekonomi, Universitas Tidar \\ Jl. Kapten Suparman, Tuguran, Potrobangsan, Kota Magelang, Jawa Tengah 56116 \\ email: panjikusuma@untidar.ac.id
}

\begin{abstract}
Abstrak
Kampung Code telah berhasil merubah lingkungannya yang semula kumuh menjadi kampung yang bersih dan rapi, sehingga menjadi salah satu kampung wisata di Kota Yogyakarta. Bangunan di Kampung Code dicat dengan warna-warna terang yang menarik banyak wisatawan untuk berkunjung. Namun meskipun demikian, Kampung Code memiliki masalah, yakni sampah di sungai yang menumpuk. Berdasarkan hasil wawancara mahasiswa Universitas Negeri Yogyakarta dengan salah seorang warga Kampung Code, sampah tersebut berasal dari masyarakat luar Kampung Code, biasanya pedagang kaki lima yang membuang sampah dari atas jembatan Gondolayu. Untuk memecahkan masalah tersebut, koperasi daur sampah merupakan solusinya. Koperasi daur sampah merupakan koperasi yang mengumpulkan sampah untuk didaur ulang. Tujuan dari adanya koperasi ini, masyarakat akan mendapatkan dana untuk pembangunan desa. Berikut adalah beberapa tahapan cara untuk mengajak masyarakat Kampung Code dalam mengembangkan koperasi daur sampah: 1) Sosialisasi, 2) Pelatihan Pembuatan Kerajinan, 3) Pelatihan Pembukuan, 4) Pembentukan Kepengurusan Koperasi, 4) Evaluasi Kinerja Koperasi Daur sampah. Dana tersebut didapat dari sampah yang diolah oleh masyarakat Kampung Code menjadi barang kerajinan yang kemudian dijual melalui koperasi tersebut. Melalui program koperasi daur sampah ini, sampah yang menumpuk di sungai bisa dimanfaatkan dengan baik oleh masyarakat sekitar dan tingkat kesejahteraan masyarakat Kampung Code dapat meningkat. Dengan begitu, Kampung Code dapat menarik wisatawan domestik atau mancanegara untuk berkunjung ke Kampung Code.
\end{abstract}

Kata Kunci: Koperasi, Sampah, Kerajinan

\section{Pendahuluan}

Salah satu permasalahan besar yang dialami kota-kota besar di Indonesia adalah persampahan. Sampah dapat diartikan sebagai konsekuensi adanya aktivitas kehidupan manusia (residu). Tidak dapat dipungkiri, sampah akan selalu ada selama aktivitas kehidupan masih terus berjalan. Setiap tahunnya, dapat dipastikan volume sampah akan selalu bertambah seiring dengan pola konsumerisme masyarakat yang semakin meningkat. Kementerian Lingkungan Hidup mencatat rata-rata penduduk Indonesia menghasilkan sekitar 2,5 liter sampah per hari atau 625 juta liter dari jumlah total penduduk (Suryani, 2014). Volume sampah yang dihasilkan berkoreasli dengan jumalah penduduk. Urbanisasi dari desa ke kota menyebabkan jumlah penduduk semakin meningkat serta volume sampah yang dihasilkan akan meningkat (Tanuwijaya, 2016). Pertambahan jumlah penduduk di kota menyebabkan 
ISSN : $2620-4665$ (print)

ISSN : $2620-4673$ (online)

Website : http://jurnal.untan.ac.id/index.php/JPLP2KM

konsentrasi peningkatan volume sampah semakin besar. Permasalahan seperti persaingan diantara masyarakat semakin ketat ataupun urbanisasi dari desa ke kota semakin tinggi saja, tetapi juga menjadi penyebab limbah buangan yang disebut sebagai sampah semakin bertambah jumlahnya.

Kampung Code merupakan salah satu lokasi yang mengalami permasalahan terhadap sampah. Kampung yang terletak di bantaran sungai Code ini mengalami masalah sampah yang cukup serius, sehingga jika tidak ditangani dengan tepat, saat musim hujan dapat menyebabkan banjir. Sampah tersebut berasal dari masyarakat luar Kampung Code, biasanya pedagang kaki lima yang membuang sampah dari atas jembatan Gondolayu. Selain itu, sampah-sampah tersebut juga berasal dari lingkungan masyarakatnya sendiri. Seiring dengan meningkatnya laju pertumbuhan penduduk kawasan Sungai Code pun menjadi sasaran untuk dijadikan daerah permukiman. Akibatnya permasalahan di daerah aliran Sungai Code pun menjadi sangat kompleks. Mulai terjadinya pencemaran air sungai, penyempitan badan sungai, tingginya erosi dan sedimentasi, hingga berujung pada seringnya terjadi banjir di daerah aliran Sungai Code. Sungai Code menunjukkan kualitas air terburuk, dibandingkan sungai lainnya yang melintas di Kota Yogyakarta, karena bakteri Coliform Tinja terdeteksi paling tinggi dan kandungan oksingen terlarut paling rendah (Brontowiyono, Kasam, L, \& A, 2013).

Municipal Solid Waste Management (MSWM) merupakan sistem pengelolaan sampah di India. Mengingat jumlah penduduk di India mengalami peningkatan setiap tahun maka harus ada upaya untuk mereduksi jumlah sampah yang ada (Sharholy, Ahmad, Mahmood, \& Trivedi, 2008). Pengelolaan sampah perlu ditangani dengan keseriusan. Meningkatkan pemahaman masyarakat untuk mengelola sampah dengan peraturan resmi sangat dibutuhkan. Partisipasi masyarakat dalam pengelolaan sampah sangat tergantung kepada pemahaman, kemauan dan pendapatan masyarakat untuk dapat meningkatkan kualitas lingkungan (Yuliastuti, Nyoman, Ayu, Yasa, Mahaendra, \& Jember, Made, 2013). Studi kasus pengelolaan sampah rumahtangga di Wedomartani (Sleman, Yogyakarta, Daerah Istimewa) dan Banjarsari (Jakarta Selatan) memberikan perspektif alternatif untuk meminimalisasi timbunan sampah yang dikelola oleh pemerintah melalui skenario daur ulang sampah dengan mengkombinasikan aspek teknis, ekologi, ekonomi, sosial budaya, kebijakan dan kelembagaan (Utami, Indrasti, \& Dharmawan, 2008). Kegiatan bank sampah merupakan konsep pengumpulan sampah kering dan dipilah serta memiliki manajemen layaknya perbankan tapi yang ditabung bukan uang melainkan sampah. Pemberdayaan warga melalui kegiatan penyuluhan, edukasi, pelatihan dengan metode partisipasi emansipatoris (interaksi dan komunikasi), serta dialog dengan warga di komunitas (Asteria \& Heruman, 2016).

Untuk memecahkan masalah persampahan di Kampung Code, koperasi daur sampah merupakan solusi yang ditawarkan. Koperasi daur sampah merupakan koperasi yang mengumpulkan sampah untuk didaur ulang. Tujuan dari adanya koperasi ini adalah untuk menumbuhkan kreatifitas warga dengan mengolah sampah menjadi sebuah kerajinan yang bernilai ekonomi. Selain itu, koperasi ini juga bermanfaat bagi masyarakat untuk menghimpun dana yang nantinya dana tersebut akan disalurkan untuk pembangunan dan kebutuhan warga dalam mengembangkan usahanya. Pengelolaan sampah melalui kelembagaan memberikan 


\section{JURNAL PENGABDI \\ APRIL 2020, Volume 3 Nomor 1}

manfaat kepada warga, terutama manfaat langsung dengan berkurangnya timbulan sampah di komunitas, lingkungan menjadi lebih bersih dan asri, serta kemandirian warga secara ekonomi. Selain manfaat secara ekonomi, dimana dari tabungan sampah memperoleh uang untuk membayar listrik dan membeli sembako, juga terwujudnya kesehatan lingkungan, dengan kondisi komunitas yang lebih bersih, hijau, nyaman, dan sehat. Pengelolaan sampah terintegrasi dapat menstimulasi kreativitas dan inovasi dari masyarakat sehingga meningkatkan kesejahteraan warga. Manfaat dari kegiatan pengelolaan sampah dengan konsep 3R yang merupakan indikator keberhasilan kegiatan menempatkan partisipasi masyarakat dalam sebuah siklus, dimana manfaat dari kegiatan pengelolaan sampah dengan konsep 3R yang dirasakan oleh masyarakat inilah yang membuat masyarakat merasa memiliki dan bertanggungjawab akan keberlangsungan kegiatan serta menjadikan partisipasinya dalam kegiatan sebagai budaya dan bagian dari kehidupannya sehari-hari (Puspitawati \& Rahdriawan, 2012).

Dalam perkembangannya, Kampung Code telah berhasil merubah lingkungannya yang semula kumuh menjadi kampung yang bersih dan rapi, sehingga menjadi salah satu kampung wisata di Kota Yogyakarta. Bangunan di Kampung Code dicat dengan warna-warna terang yang menarik banyak wisatawan untuk berkunjung. Namun meskipun demikian, permasalahan

sampah di Kampung Code belum bisa teratasi. Sampah yang menumpuk di sepanjang aliran sungai sangat mengganggu pemandangan Kampung Code, sehingga membuat kampung ini terlihat kumuh. Selain itu, kotornya sungai juga dapat menjadi sarang penyakit bagi masyarakat sekitar. Pengelolaan sampah yang dilakukan dengan manajemen yang benar akan lebih menguntungkan jika dibandingkan dengan biaya yang harus dikeluarkan untuk mengatasi permasalahan lingkungan akibat sampah (Beigl \& Salhofer, 2004).

Permasalahan lain yang dihadapi oleh Kampung Code ialah keterbatasan dana untuk pembangunan. Hal ini dikarenakan tidak adanya dana dari Pemerintah seperti kampungkampung yang lain. Warga Kampung Code tidak dapat mengajukan permintaan dana ke pemerintah karena tanah mereka tidak bersertifikat atau masih berstatus illegal. penelitian menyimpulkan bahwa kurangnya sumber daya. Permasalahan yang dihadapi MSWM di India seperti pembiayaan, infrastruktur, perencanaan dan data yang sesuai, dan kepemimpinan, adalah hambatan utama dalam MSWM. Peningkatan permintaan layanan dikombinasikan dengan kurangnya sumber daya untuk kota menempatkan beban besar pada sistem MSWM yang ada (Sharholy et al., 2008). Dari permasalah tersebut, koperasi daur sampah sangat diperlukan di Kampung Code untuk mengatasi masalah sampah dan masalah dana yang sedang dihadapi oleh Kampung Code. Diperlukan adanya dukungan kelembagaan yang resmi supaya hambatan dalam pengelolaan sampah dapat teratasi.

Berdasarkan Kamus Besar Bahasa Indonesia (KBBI), sampah adalah barang atau benda yang dibuang karena tidak terpakai lagi dan sebagainya. Menurut definisi World Health Organization (WHO), sampah adalah sesuatu yang tidak digunakan, tidak dipakai, tidak disenangi atau sesuatu yang dibuang yang berasal dari kegiatan menusia dan tidak terjadi dengan sendirinya. Sampah adalah buangan berupa bahan padat yang menyebabkan turunnya nilai estetika lingkungan, nilai sumber daya, membawa penyakit, menyumbat saluran air, menimbulkan polusi dan banyak dampak negatif lainnya. Sedangkan, menurut Azwar, sampah 
ISSN : $2620-4665$ (print)

ISSN : $2620-4673$ (online)

Website : http://jurnal.untan.ac.id/index.php/JPLP2KM

adalah sesuatu yang tidak disenangi, tidak terpakai, berasal dari kegiatan manusia dan bersifat padat. Menurut Ryadi (1986), sampah merupakan sebagian benda atau hal-hal yang dipandang tidak dapat digunakan lagi, tidak dipakai, tidak disenangi, atau harus dibuang sedemikian rupa sehingga tidak sampai mengganggu kelangsungan hidup.

Menurut Daniel (2009), terdapat tiga jenis sampah, yaitu: 1) Sampah Organik (Sampah Basah) yaitu sampah yang terdiri dari bahan-bahan yang bisa terurai secara alamiah atau biologis. Seperti sisa makanan dan guguran daun. Sampah jenis ini juga biasa disebut sampah basah. 2) Sampah Anorganik (Sampah Kering) Sampah yang terdiri dari bahan-bahan yang sulit terurai secara biologis. Proses penghancurannya membutuhkan penanganan lebih lanjut di tempat khusus. Misalnya plastic, kaleng, dan Styrofoam. Sampah jenis ini juga biasa disebut sampah kering. 3) Sampah B3 (Bahan Beracun dan Berbahaya) yaitu limbah dari bahan yang beracun dan berbahaya seperti limbah rumah sakit, limbah pabrik, pertambangan, dan sebagainya.

Sampah perlu dikelola agar tidak menimbulkan dampak negatif bagi lingkungan. Sampah yang dibuang dari berbagai sumber dapat dibedakan menjadi sampah organik dan anorganik. Pada satu sisi, sampah organik dapat menjadi makanan bagi ikan. Akan tetapi sampah dapat mengurangi kadar oksigen. Sampah anorganik dapat mengurangi sinar matahari yang masuk ke dalam lingkungan perairan. Akibatnya, proses esensial dalam ekosistem seperti fotosintesis menjadi terganggu. Selain itu, sampah-sampah tersebut menyebabkan air menjadi keruh. Kondisi ini akan mengurangi organisme yang dapat hidup dalam kondisi tersebut. Akhirnya populasi hewan maupun tumbuhan tertentu berkurang.

Penelitian terkait dengan pemberdayaan masyarakat untuk mengelola sampah yang dilakukan (Harahap, 2017, Tanuwijaya, 2016) menunjukkan bahwa pemberdayaan yang menggunakan koperasi sebagai salah satu strategi pember- dayaannya tidak hanya sebatas untuk mengejar atau bertujuan untuk pemenuhan dalam meningkatkat taraf ekonomi saja, tetapi pemberdayaan yang dilakukan oleh Koperasi Bangkit Bersama juga menjadikan Pelestarian Lingkungan sebagai basis dari pemberdayaan mereka. Karena pemberdaya- an yang sesungguhnya adalah memampukan masyarakat dengan mengoptimalkan ke- mampuan yang masyarakat miliki tanpa harus ada yang harus dirusak.

Penelitian Utami et al., (2008) pengembangan pengelolaan sampah pada sumbernya sangat dipengaruhi oleh bentuk inisiasi dan pendampingan pemimpin lokal. Pola pengelolaan sampah di Wedomartani yang berbasis industri lebih efektif dalam mereduksi sampah rumah tangga dibanding pola Banjarsari yang berbasis. Pengembangan pengelolaan sampah merupakan salah satu upaya agar permasalahan sampah dapat diatasi dengan cara membentuk komunitas/lembaga pengelolaan sampah. Sehingga, masyarakat dapat bertanggung jawab atas persoalan sampah di lingkungannya.

\section{Metode}

Saat ini masalah yang dihadapi Kampung Code terletak pada sampah dan kekurangan dana. Banyaknya sampah di sekitar Kampung Code membuat kampung ini terlihat kotor dan kumuh. Sementara itu, Kampung Code tidak mendapatkan dana dari pemerintah, sehingga 
mengalami kesulitan dalam mengembangkan lingkungan Kampung Code. Koperasi daur sampah merupakan koperasi yang mengumpulkan sampah untuk didaur ulang. Tujuan dari adanya koperasi ini adalah untuk menumbuhkan kreatifitas warga dengan mengolah sampah menjadi sebuah kerajinan yang bernilai ekonomi. Selain itu, koperasi ini juga bermanfaat bagi masyarakat untuk menghimpun dana yang nantinya dana tersebut akan disalurkan untuk pembangunan dan kebutuhan warga dalam mengembangkan usahanya. Penelitian ini menggunakan pendekatan penelitian kualitatif, tujuannya adalah mendeskripsikan kondisi pengelolaan sampah di Kampung Code dan solusi yang harus diberikan agar pengelolaan sampah di Kampung Code dapat ditangani dengan kelembagaan yang tepat.

Pengembangan koperasi daur sampah di Kampung Code diharapkan dapat mengatasi dua permasalahan yang dihadapi oleh Kampung Code saat ini. Koperasi ini berfungsi sebagai wadah masyarakat untuk mendaur ulang sampah kering yang menumpuk di lingkungan mereka untuk dijadikan sebuah kerajinan yang bernilai jual. Adanya koperasi daur sampah ini juga membantu masyarakat secara langsung dalam pendanaan, baik dari segi pembangunan maupun ekonomi

\section{Pembahasan}

a. Peran Masayarakat Kampung Code Dalam Mengembangkan Koperasi Daur Sampah

Pengelolaan sampah di kampung ini belum cukup efektif dalam mengatasi penumpukan sampah, terutama sampah yang berasal dari sungai Code. Selain itu, tempat pembuangan sampah umum di Kampung Code hanya dapat menciptakan kawasan bersih di sekitar perumahan penduduk saja. Sementara di luar lingkungan warga Kampung Code, sampah masih menumpuk karena masyarakat merasa bahwa itu bukan daerahnya. Kurangnya kepedulian dari pemerintah juga membuat pengelolaan sampah di kampung Code kurang maksimal. Permasalahan tersebut, tentunya harus segera diatasi. Salah satu solusi untuk mengatasi masalah ini adalah pendirian koperasi daur sampah. Koperasi ini berfungsi sebagai wadah masyarakat untuk mengolah sampah kering. Sampah kering ini nantinya akan dibuat kerajinan sehingga bernilai jual. Selain itu dengan adanya koperasi ini juga dapat menghimpun dana sebagai sumber dalam pendanaan pembangunan dan ekonomi bagi Kampung Code. 
ISSN : $2620-4665$ (print)

ISSN : $2620-4673$ (online)

Website : http://jurnal.untan.ac.id/index.php/JPLP2KM

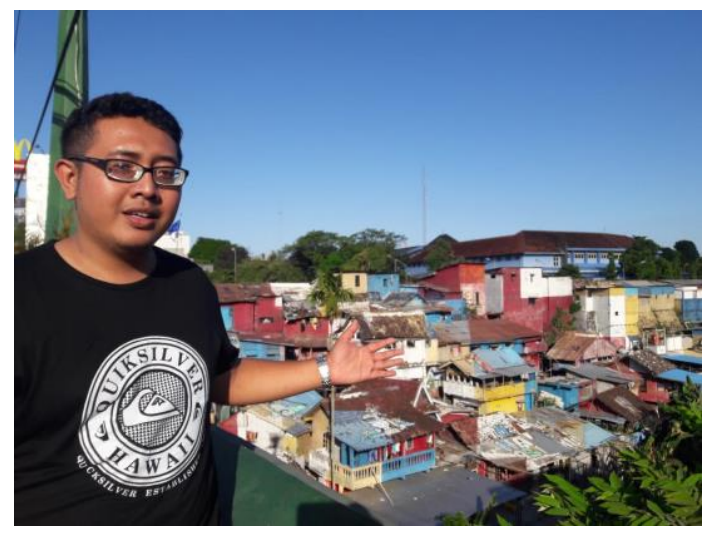

Gambar 1. Lokasi Mitra Kampung Code

Dalam mendirikan koperasi, tentunya membutuhkan dukungan dari masyarakat Kampung Code, karena keberlangsungan koperasi tergantung pada peranan anggotanya. Untuk itu, dibutuhkan cara untuk mengajak masyarakat Kampung Code agar ikut serta dalam mendirikan dan mengembangkan koperasi daur sampah tersebut. Beberapa tahapan cara untuk meningkatkan peran masyarakat Kampung Code dalam mengembangkan koperasi daur sampah:

1) Sosialisasi

Dalam tahap ini, masyarakat akan diberitahu pentingnya menjaga kebersihan dan mengelola sampah secara efektif. Pada tahap ini masyarakat juga akan diberikan sosialisasi tentang koperasi daur sampah. Tujuan dari sosialisasi ini adalah agar masyarakat dapat memanfaatkan sampah untuk menjadi barang yang bermanfaat atau bernilai jual melalui koperasi daur sampah.

2) Pelatihan Pembuatan Kerajinan

Dalam tahap ini masyarakat akan diajarkan untuk membuat berbagai macam kerajinan berbahan dasar sampah kering yang masih bisa digunakan seperti plastik, kaleng bekas, botol bekas, gabus dan lain sebagainya. Selain itu masyarakat juga diajarkan bagaimana cara membuat kerajinan tersebut agar layak dijual.

3) Pelatihan Pembukuan

Pelatihan ini ditujukan kepada masyakat Kampung Code agar dapat mengelola keuangannya dalam kegiatan usaha. Pelatihan pembukuan juga sebagai bekal awal dalam mengelola koperasi daur sampah kedepannya.

4) Pembentukan Kepengurusan Koperasi

Dalam sebuah Organisasi tentu perlu adanya pengurus, karena pengurus merupakan bagian yang mengatur sebuah Organisasi dalam perencanaan, pengelolaan, pengendalian dan pelaksana kegiatan dalam Organisasi. Begitupun dalam pembentukan koperasi tentu perlu adanya pengurus sebagai pelaksana fungsi sebuah organisasi.

5) Evaluasi Kinerja Koperasi Daur sampah 
Tahap terakhir adalah evaluasi kinerja dari koperasi tersebut. Gunanya untuk melihat apakah koperasi tersebut sudah berjalan sesuai dengan rencana yang telah ditetapkan. Tahap ini dilakukan setiap bulannya agar kinerja koperasi ini meningkat.

\section{b. Koperasi Daur Sampah dalam Mengatasi Sampah}

Peran koperasi ialah sebagai penggerak dalam perekonomian masyarakat. Koperasi didirikan untuk meningkatkan kesejahteraan anggotanya. Dalam hal ini, anggota dari koperasi daur sampah ialah masyarakat Kampung Code itu sendiri. Sehingga, keberadaan koperasi daur sampah adalah untuk meningkatkan kesejahteraan masyarakat Kampung Code.

Berbeda dengan bank sampah, koperasi daur sampah memiliki fungsi yang tidak dimiliki oleh bank sampah. Jika bank sampah hanya mengumpulkan dan mengolah sampah menjadi kerajinan, koperasi daur sampah berfungsi juga sebagai sumber pendanaan bagi masyarakat Kampung Code. Pada koperasi daur sampah masyarakat akan diajarkan bagaimana membuat kerajinan dari sampah yang layak untuk dijual dan dijadikan oleh-oleh khas Kampung Code. Pada Koperasi daur sampah, masyarakat dapat meminjam dana untuk pengembangan usaha. Dengan demikian koperasi ini dapat meningkatkan kesejahteraan masyarakat disana sekaligus menjaga kebersihan dengan pengelolaan sampah yang lebih efektif. Pengelolaan sampah melalui koperasi sampah harus memperhatikan aspek-aspek manajemen persampahan. Aspek tersebut digunakan sebagai acuan pengelola agar memiliki struktur kelembagaan yang tepat.

Tabel 1. Aspek-aspek Manajemen Persampahan

\begin{tabular}{|c|c|c|c|}
\hline No & Aspek & Peran Pokok & Keterangan \\
\hline 1 & $\begin{array}{l}\text { Aspek } \\
\text { Kelembagaan }\end{array}$ & $\begin{array}{l}\text { Menggerakkan, } \\
\text { mengaktifkan } \\
\text { dan } \\
\text { mengarahkan } \\
\text { sistem }\end{array}$ & $\begin{array}{l}\text { Terdiri dari: } \\
\text { - Bentuk dan pola pengembangan } \\
\text { - } \text { Sistem manajemen (perencanaan, } \\
\text { pelaksanaan dan pengendalian } \\
\text { untuk jenjang strategis, teknik } \\
\text { maupun operasional) }\end{array}$ \\
\hline 2 & $\begin{array}{l}\text { Aspek } \\
\text { Pembiayaan }\end{array}$ & $\begin{array}{l}\text { Merupakan } \\
\text { komponen } \\
\text { sumber dalam } \\
\text { arti supaya } \\
\text { sistem } \\
\text { mempunyai } \\
\text { kinerja yang } \\
\text { baik }\end{array}$ & $\begin{array}{l}\text { Struktur pembiayaan terdiri dari: } \\
-\quad \text { Anggaran } \\
\text { - } \quad \text { Alternative sumber pendapatan }\end{array}$ \\
\hline
\end{tabular}


ISSN : $2620-4665$ (print)

ISSN : 2620-4673 (online)

Website : http://jurnal.untan.ac.id/index.php/JPLP2KM

\begin{tabular}{|c|c|c|c|}
\hline 3 & $\begin{array}{l}\text { Aspek } \\
\text { Pengaturan } \\
\text { (dasar hukum) }\end{array}$ & $\begin{array}{l}\text { Komponen yang } \\
\text { menjaga } \\
\text { pola/dinamika } \\
\text { sistem agar } \\
\text { dapat mencapai } \\
\text { sasaran secara } \\
\text { efektif }\end{array}$ & $\begin{array}{l}\text { Fungsi dari peraturan } \\
\text { - Sebagai landasan pendirian instansi } \\
\text { pengelola (dinas, perusahaan } \\
\text { daerah dan lainnya) } \\
\text { - } \mathrm{S} \\
\text { st } \\
\text { - Sebagai landasan ketertiban umum } \\
\text { (masyarakat) dalam pengelolaan } \\
\text { persampahan }\end{array}$ \\
\hline 4 & $\begin{array}{l}\text { Aspek Peran } \\
\text { Serta } \\
\text { Masyarakat }\end{array}$ & $\begin{array}{l}\text { Komponen yang } \\
\text { tidak bersifat } \\
\text { subsistem tapi } \\
\text { terkait erat } \\
\text { sebagai } \\
\text { penyedia } \\
\text { kapasitas kerja } \\
\text { maupun } \\
\text { pendanaan }\end{array}$ & $\begin{array}{l}\text { Bentuk peran serta masyarakat dalam: } \\
\text { - Teknis operasional pengumpulan } \\
\text { sampah dari mulai sumber sampai } \\
\text { pembuangan akhir } \\
\text { - Pendanaan }\end{array}$ \\
\hline 5 & $\begin{array}{l}\text { Aspek Teknik } \\
\text { Operasional }\end{array}$ & $\begin{array}{l}\text { Komponen yang } \\
\text { paling dekat } \\
\text { dengan obyek } \\
\text { pengelolaan } \\
\text { sampah }\end{array}$ & $\begin{array}{l}\text { Terdiri dari sarana, prasarana, } \\
\text { perencanaan, dan tata cara teknik } \\
\text { operasional pengelolaan sampah untuk } \\
\text { kegiatan: } \\
\text { - Pewadahan } \\
\text { - Pengumpulan } \\
\text { - Pengangkutan } \\
\text { - Pembuangan Akhir }\end{array}$ \\
\hline
\end{tabular}

Sumber: "Dasar Pengelolaan Sampah Kota” dalam (Suryani, 2014)

Prinsip koperasi daur sampah adalah sistem bagi hasil. Setiap ada penjualan kerajinan maka hasil penjualan tersebut akan dibagi dua, sebagian untuk masyarakat dan sebagian untuk tambahan pendanaan koperasi, selain dari iuran anggota. Hasil penjualan yang disisihkan untuk koperasi ini nantinya akan menjadi sumber pendanaan tambahan bagi koperasi yang dapat dipinjamkan kepada masyarakat untuk mengembangkan usahanya. Penelitian (Harahap, 2017) mengenai pemberdayaan yang dilakukan oleh Koperasi Bangkit Bersama merupakan jenis usaha sadar yang dilakukan oleh masyarakat setempat untuk mengatasi keterbelakangan atau kesusahan yang mereka hadapi. Dengan menggunakan pendekatan bottom up pemberdayaan yang dilakukan oleh koperasi selalu bertumpu kepada kebutuhan dan berdasarkan permasalahan yang sedang di- hadapi oleh masyarakat, karena bagi kope- rasi Bangkit Bersama konsep pemberdayaan mereka adalah masyarakat harus sebagai subjek dan objek dari 
pemberdayaan itu sendiri karena pemberdayaan yang berasal dari masyarakat, oleh masyarakat dan untuk masyarakat.

Manfaat lain yang diperoleh melalui kelembagaan koperasi sampah adalah penguatan financial ketika masyarakat membutuhkan tambahan pendanaan. Koperasi sampah menjadi sumber pendaanaan bagi masyarakat Kampung Code dalam hal pengelolaan sampah dan lingkungan. Apabila dikelola dengan benar, kedepannya koperasi ini dapat menerakan fungsi sebagai KUR (Kredit Usaha Rakyat). Fungsi KUR pada koperasi akan mendorong masyarakat untuk meminjam dana di koperasi, sehingga menghindari masyarakat terlilit bunga hutang BPR (Bank Perkreditan Rakyat).

\section{Kesimpulan}

Kampung Code merupakan sebuah kampung yang terletak di pinggiran Sungai Code. Kampung ini memiliki dua masalah utama, yakni pengolahan sampah yang tidak efektif dan kurangnya pendanaan dalam pembangunan kampung dan usaha. Untuk mewujudkan Kampung Code yang bersih dan menciptakan masyarakat Kampung Code yang sejahtera, diperlukan adanya koperasi daur sampah. Koperasi daur sampah merupakan koperasi yang mengumpulkan sampah untuk didaur ulang. Tujuan dari koperasi ini adalah untuk menumbuhkan kreatifitas warga dengan mengolah sampah menjadi sebuah kerajinan yang bernilai ekonomi dan menghimpun dana yang nantinya dana tersebut akan disalurkan untuk pembangunan dan pengembangan usaha. Berikut adalah beberapa tahapan cara untuk mengajak masyarakat Kampung Code dalam mengembangkan koperasi daur sampah: 1) Sosialisasi, 2) Pelatihan Pembuatan Kerajinan, 3) Pelatihan Pembukuan, 4) Pembentukan Kepengurusan Koperasi, 4) Evaluasi Kinerja Koperasi Daur sampah. Berbeda dengan bank sampah, koperasi daur sampah berfungsi sebagai sumber pendanaan bagi masyarakat Kampung Code. Pada koperasi ini masyarakat akan diajarkan bagaimana membuat kerajinan dari sampah yang layak untuk dijual. Pada Koperasi daur sampah, masyarakat dapat meminjam dana untuk pengembangan usaha.

Diharapkan masyarakat Kampung Code ikut serta dalam pengembangan koperasi daur sampah ini, sehingga masalah yang ada di Kampung Code dapat teratasi dan dapat meningkatkan kesejahteraan masyarakat Kampung Code. Dengan adanya Koperasi Daur Sampah dapat menciptakan lingkungan Kampung Code menjadi bersih serta nyaman untuk dikunjungi. Hal ini juga dapat menarik wisatawan dari luar daerah untuk mengunjungi Kampung Code.

\section{Ucapan Terima Kasih}

Penelitian ini didanani oleh dana DIP LPPM-PMP Universitas Tidar. Terimaksih kami ucapkan kepada pihak terkait yang telaj membantu dalam pelaksanaan penelitian ini. 
ISSN : $2620-4665$ (print)

ISSN : $2620-4673$ (online)

Website : http://jurnal.untan.ac.id/index.php/JPLP2KM

\section{Daftar Pustaka}

A.L. Slamet Ryadi. 1986, Pengantar Kesehatan Lingkungan. Surabaya: Usaha Nasional Asteria, D., \& Heruman, H. (2016). BANK SAMPAH SEBAGAI ALTERNATIF STRATEGI PENGELOLAAN SAMPAH BERBASIS MASYARAKAT DI TASIKMALAYA (Bank Sampah (Waste Banks) as an Alternative of CommunityBased Waste Management Strategy in Tasikmalaya). Jurnal Manusia Dan Lingkungan, 23(1), 136. https://doi.org/10.22146/jml.18783

Beigl, P., \& Salhofer, S. (2004). Comparison of ecological effects and costs of communal waste management systems. Resources, Conservation and Recycling, 41(2), 83-102. https://doi.org/10.1016/j.resconrec.2003.08.007

Brontowiyono, W., Kasam, K., L, R., \& A, I. (2013). Strategi Penurunan Pencemaran Limbah Domestik di Sungai Code DIY. Jurnal Sains \&Teknologi Lingkungan, 5(1), 36-47. https://doi.org/10.20885/jstl.vol5.iss1.art5

Harahap, F. (2017). Pemberdayaan Masyarakat Pemulung Sampah Sungai Citarum Melalui Koperasi Bangkit Bersama Empowering Garbage-Gathering Community in Citarum River through Bangkit Bersama Cooperation. Jurnal Pendidikan Dan Pemberdayaan Masyarakat, 4(2), 180-186.

Puspitawati, Y., \& Rahdriawan, M. (2012). Kajian Pengelolaan Sampah Berbasis Masyarakat dengan Konsep 3R (Reduce, Reuse, Recycle) di Kelurahan Larangan Kota Cirebon. $\begin{array}{lllll}\text { Jurnal Pembangunan Wilayah \& } & \text { Kota, } & \text { 8(4), }\end{array}$ https://doi.org/10.14710/pwk.v8i4.6490

Sharholy, M., Ahmad, K., Mahmood, G., \& Trivedi, R. C. (2008). Municipal solid waste management in Indian cities - A review. Waste Management, 28(2), 459-467. https://doi.org/10.1016/j.wasman.2007.02.008

Suryani, A. S. (2014). Peran Bank Sampah Dalam Efektivitas Pengelolaan Sampah (STUDI KASUS BANK SAMPAH MALANG). Aspirasi, 5(1), 71-84.

Tanuwijaya, F. (2016). DI BANK SAMPAH PITOE JAMBANGAN Fransiska Tanuwijaya. Partisipasi Masyarakat Dalam Pengelolaan Sampah Di Bank Sampah Pitoe Jambangan Kota Surabaya, 4, 230-244.

Utami, B. D., Indrasti, N. S., \& Dharmawan, A. H. (2008). Pengelolaan Sampah Rumahtangga Berbasis Komunitas: Teladan dari Dua Komunitas di Sleman dan Jakarta Selatan. Sodality - Jurnal Sosiologi Pedesaan, 2(1), 49-68. https://doi.org/10.22500/sodality.v2i1.5893

Yuliastuti, Nyoman, Ayu, I., Yasa, Mahaendra, N. I., \& Jember, Made, I. (2013). PARTISIPASI MASYARAKAT DALAM PENGELOLAAN SAMPAH DI KABUPATEN BADUNG. E- Ekonomi Bisnis Universitas Udayana, 02, 374-393. Retrieved from http://ojs.unud.ac.id/index.php/EEB/article/view/5380 